\title{
COMMUNITY VIEWS ON THE ROLE OF TOURISM IN LOCAL DEVELOPMENT: A SOUTH AFRICAN STUDY
}

\author{
Takalani RAMUKUMBA* \\ Nelson Mandela University, Department of Tourism, Faculty of Business and Economic \\ Sciences, George, South Africa, e-mail: Takalani.Ramukumba@mandela.ac.za
}

\begin{abstract}
Citation: Ramukumba, T. (2019). COMMUNITY VIEWS ON THE ROLE OF TOURISM IN LOCAL DEVELOPMENT: A SOUTH AFRICAN STUDY. GeoJournal of Tourism and Geosites, 25(2), 638-647. https://doi.org/10.30892/gtg.25228-386
\end{abstract}

\begin{abstract}
Tourism has received much attention recently as a viable avenue to boost local economies and stimulate growth and development in sub-Saharan Africa with tourism strategies being adopted by many local authorities in South Africa as a major part of their local economic development (LED) initiatives. While much focus has been on approaches and strategies to use tourism for LED, minimal attention has been paid to the actual views and opinions of community members with regard to these approaches and strategies. This study, hence, evaluates communities' views on the role of tourism in local economic development. The study was conducted in Mnquma local municipality, Eastern Cape Province, South Africa, adopted a quantitative research methodology, and used questionnaires as data collection instrument. Key results indicate that community members feel that the tourism industry is not yet at a stage where it is able to contribute to poverty alleviation and create employment opportunities in the local municipality.
\end{abstract}

Key words: Local economic development; tourism resources; South Africa; Mnquma local municipality; community perceptions

\section{INTRODUCTION}

Local economic development planning is attracting a growing inter-disciplinary scholarship (Rodriguez-Pose \& Tijmstra, 2007; Pike et al., 2011). Its core purpose is to build up the economic capacity of a local area to improve local economic futures and the quality of life for all (Nel \& Rogerson, 2005; Pike et al., 2011). It is a process by which public, business and non-governmental sector partners work collectively to create better conditions for economic growth and employment generation (Ramukumba, 2012). Research on local economic development is particularly significant for developing countries in order to address critical development challenges (Barberia \& Biderman, 2010). Across sub-Saharan Africa, planning for LED is a critical element in development planning and has attracted a growing scholarship (Rodriguez-Pose \& Tijmstra, 2007; Rogerson \& Rogerson, 2010; Rogerson, 2014; Rogerson \& Rogerson, 2014; Lawrence \&

\footnotetext{
* Corresponding author
} 
Rogerson, 2018; Drummond \& Snowball, 2019). In South Africa, LED is one of the main functions of local government and, currently, many of the country's local authorities are focusing on tourism as a catalyst for local economic development (Rogerson, 2013; Nel \& Rogerson, 2016; Rogerson, 2019; Rogerson \& Rogerson, 2019a). This surge towards using tourism as a strategy for local economic development has been boosted by the South African national government with its promotion of tourism as part of its national development planning strategies (Rogerson \& Rogerson, 2018).

Rogerson (2013), in support of the above, stated that national government recognises and acknowledges the critical role of local governments in supporting tourism development and, as such, the national government has started introducing several support initiatives to capacitate these local governments. Indeed, in South Africa, the importance of promoting local development "is increasingly being identified as the strategic enabler for national economic and development objectives" especially of the country's National Development Plan (Van der Merwe \& Rogerson, 2018). These same authors went further to state that for many economically declining localities faced with the downturn of resource-based activities (particularly in mining and agriculture), tourism has become a 'last resort' for regenerating these marginalized areas. Much focus in existing scholarship on South Africa is on approaches and strategies to use tourism for LED with limited attention paid to the actual views and opinions of community members on these approaches and strategies. In one study, Mabaso (2010) researched the perceptions of key stakeholders in local communities of tourism and found they had a diverse understanding of the role of tourism in local economic development and what needs to be in place for tourism to be a key driver for local economic development.

The current study was to extends the literature on community views of the role of tourism in local development. This study was conducted in Mnquma local municipality which is in South Africa's Eastern Cape province. It is a remote and mainly rural area with high levels of poverty and unemployment. The locality is situated within the underdeveloped and economically distressed areas of the country (Rogerson \& Nel, 2016). Arguably, in terms of the national space economy of tourism, the Mnquma local municipality is one of the less visited tourism spaces of South Africa (Rogerson, 2017; Rogerson \& Rogerson, 2019b). Nevertheless, in common with many peripheral rural municipalities across South Africa, local planning documents for Mnquma identify tourism as a key potential sector to advance local economic development objectives and call for its prioritisation in future local development planning.

\section{TOURISM AND LOCAL ECONOMIC DEVELOPMENT}

According to Pike et al. (2011: 2), whilst over the past two decades there is recorded a growth in scholarship surrounding local economic development, studies relating to questions of tourism as a driver of local economic development is limited. Indeed, in the most recent high-profile international volume capturing the state of the art of local economic development literature, issues concerning tourism went almost entirely unrecorded (Pike et al., 2011:2). The potential of tourism to contribute significantly to economic development is based on its contributions towards the diversification of the economy, its capacity to attract people to even the most remote locations with unique culture and natural attractions, its labour-intensive nature which supports a range of local skills from low to high skills, and its dominance by small-scale enterprises.

Tourism has, hence, proven on a global scale to be an economic sector that creates opportunities of employment in both formal and informal sectors (UNWTO, 2000), providing opportunities for improvement in quality of life and as a source of foreign income. In this regard, the tourism sector serves as an alternative form of export since it 
improves the country's balance of payment and a general increase in economic activities. According to Khalil, Kakar and Malik (2007), most developing countries are focusing on tourism as an alternative for economic growth, and in sub-Saharan Africa, the significance of tourism is of increasing importance for many countries (Rogerson \& Rogerson, 2018). The tourism industry is a labour- intensive and allows for relative ease of entry into the market with limited barriers. Tourism can be an important lever for reducing poverty through both its direct impacts, such as wages, employment and training, and through its indirect impacts such as value chains from sub-sectors including food, construction, transportation, and many other sectors (Ashley et al., 2007; Rogerson \& Saarinen, 2018). Lastly, tourism exerts a range of dynamic impacts which can contribute positively to livelihood strategies for households, through infrastructure development (Ashley et al. 2007). Ramukumba (2012) noted that tourism has been seen to be a key driver for local economic development objectives such as sustainable employment, poverty alleviation and economic growth.

Kimbu \& Tichaawa (2018) suggested that it will be plausible to suggest that LED related activities should be geared towards encouraging active stakeholder participation in every locality or community. Nevertheless, there exists no single model of how to implement LED, nor strategies or actions to adopt, because factors that are mainly linked to efficiency and effectiveness of regional development are influenced by a range of institutions and processes. As discussed above the major focus in existing scholarship concerning tourism as a lead sector for LED is upon strategies and implementation. The existing literature has limited studies which explore the actual views and opinions of community members of the approaches and strategies for tourism and LED. This knowledge gap is addressed in the empirical study that was conducted in Mnquma local municipality, Eastern Cape Province, South Africa.

\section{MATERIALS AND METHODS}

Primary data for this research came from structured questionnaires completed by hundred and fifty (150) members of the community and the study adopted a quantitative research methodology. To identify insights and differences in perceptions between the respondents, a question regarding whether the respondent has a tourism qualification was included. The proposed contents of the questionnaire were discussed with key tourism stakeholders in the municipality that included the manager of tourism and local economic development, tourism officer, three tourism business owners and two local community members involved in tourism in the municipal area prior to data collection. Minor adjustments were made according to their comments and views of the questionnaire. The study adopted the convenience sampling non-probability technique in selecting participants in the survey. The views of Fox and Bayat (2007:59) are that, although units of analysis of non-probability sampling do not have an equal chance of being included in the sample, it still is frequently used because of its convenience and inexpensiveness. Convenience sampling, also known as availability sampling, is a specific type of non-probability sampling method that relies on data collection from population members who are conveniently available to participate in study.

Tashakkori and Teddlie (2003:280) describe it as a technique where elements of a sample are drawn from a group or sub-population which is readily available. According to Welman and Kruger (2001:62) it is a more opportune method, as the population is more easily accessible to participate in the research. Field workers were used to distribute the questionnaires and targeted both community members, tourism business owners and the employees within the tourism industry. The field workers that managed the completion processes of the questionnaires briefed the respondents first 
about the purpose of the study and established the willingness of the respondents to participate in the study. It was only those respondents who were willing to participate in the study that were given the questionnaires to complete. The Statistical Package for the Social Sciences (or SPSS) was used to analyse the results.

The study also analysed statistical significance on certain factors. Sarantakos (2007:63) defines statistical significance as the probability that a test result has occurred by chance. It is then expressed in terms of the level of significance and the researchers work within these levels by computing the p-value. The test value is significant if a p-value smaller than 0.05 is determined. For this study a p-value smaller than 0.05 was of significance.

\section{RESULTS DISCUSSIONS}

The data collected for the study came from one hundred and fifty (150) respondents from the Mnquma local municipality. Of the hundred and fifty respondents, $40 \%$ were males whilst $60 \%$ were females. The age distribution of the respondents shows that $54 \%$ were between the ages $21-30,36 \%$ were between $31-40$, $8 \%$ between $41-50$ whilst $2 \%$ were 51 years and above respectively.

The results further show that $4 \%$ of the respondents had primary education, $45 \%$ had secondary education whilst $51 \%$ had tertiary education qualifications. The section that follows will detail the respondent's views on various issues relating to the role of tourism in local economic development. The results in Table 1, reflects respondents' reported awareness of tourism activities in the municipal area. Most respondents (74.7\%) indicated that they were aware of tourism activities taking place in the municipal area whilst 25.3\% indicated that they were not aware.

Table 1. Respondents views on the awareness of tourism activities in the municipal area

\begin{tabular}{|c|c|c|c|}
\hline Are you aware of tourism activities in the area? & Frequency & Percent \\
\hline \multirow{3}{*}{ Valid } & Yes & 112 & 74.7 \\
\cline { 2 - 4 } & No & 38 & 25.3 \\
\cline { 2 - 4 } & Total & 150 & 100.0 \\
\hline \multicolumn{3}{|c|}{ Do you have a tourism qualification? } \\
\hline \multirow{3}{*}{ Valid } & Yes & 68 & 45.3 \\
\cline { 2 - 4 } & No & 82 & 100 \\
\cline { 2 - 4 } & Total & 150 & 100 \\
\hline
\end{tabular}

The results in Table 2, above gives an insight into respondents' views on the state of the tourism industry in Mnquma local municipality. The results generally indicate that respondents believe the current state of the tourism industry is not well suited to help the area with local economic development. If the results of those who disagreed and those who strongly disagreed are combined for all the statements, the results then indicate that more than half of the respondents disagreed with the statements. Standing out from these results is where respondents, in majority (91.3\%), disagreed with the notion that the infrastructure and superstructures available in the municipal area are in good state to support the growth of the tourism industry.

These results are in contrast with the views of Rogerson (2013:13) who pointed out that the competitive position of any destination is determined by to an extent by the diversity and quality of its resources, availability of infrastructure and services. Given the above, it is the clear that the tourism industry in the municipal area is not in a state where it can assist the tourism industry to be a strategy for local economic development. The results further infer that most respondents (70\% and 60.7\%, respectively) are is 
disagreement that the municipality has prioritised the tourism industry as a key driver of economic growth to create employment opportunities and reduce poverty levels in the area, as well as the statement that tourism is contributing towards the improvement of the standard of living for community members in the municipal area.

These results are in contrast with the views of Ashley et al. (2007) who pointed out that tourism, could reduce poverty and improve standard of living in a specific locality in various ways. Respondents are of the view that the municipal area does not have enough tourism attractions and activities to encourage sufficient tourist spending to contribute to economic growth in the area with $62 \%$ in disagreement.

Table 2. State of the tourism industry in the municipal area

\begin{tabular}{|l|c|c|c|c|c|}
\hline \multicolumn{1}{|c|}{ Statements } & $\begin{array}{c}\text { Strongly } \\
\text { Agree }\end{array}$ & Agree & Neutral & Disagree & $\begin{array}{l}\text { Strongly } \\
\text { Disagree }\end{array}$ \\
\hline $\begin{array}{l}\text { The municipality has prioritised the tourism } \\
\text { industry as a key driver of economic growth to } \\
\text { create employment opportunities and reduce } \\
\text { poverty levels in the area }\end{array}$ & $7.3 \%$ & $9.3 \%$ & $13.3 \%$ & $43.3 \%$ & $26.7 \%$ \\
\hline $\begin{array}{l}\text { Tourism is contributing towards the } \\
\text { improvement of the standard of living for } \\
\text { community members in the municipal area }\end{array}$ & $4.0 \%$ & $12.7 \%$ & $22.7 \%$ & $40.7 \%$ & $20.0 \%$ \\
\hline $\begin{array}{l}\text { Community members take advantage of } \\
\text { opportunities in the tourism industry by } \\
\text { starting their own businesses because they } \\
\text { understand the potential the industry has to } \\
\text { reduce poverty }\end{array}$ & $2.7 \%$ & $15.3 \%$ & $20.7 \%$ & $36.7 \%$ & $24.7 \%$ \\
\hline $\begin{array}{l}\text { There are enough tourism attractions and } \\
\text { activities in the municipal area to encourage } \\
\text { tourist spending that contribute to economic } \\
\text { growth in the area }\end{array}$ & $5.3 \%$ & $11.3 \%$ & $21.3 \%$ & $38.0 \%$ & $24.0 \%$ \\
\hline $\begin{array}{l}\text { The municipality has training programs to train } \\
\text { the unskilled and semi-skilled to enable them } \\
\text { to work in the tourism industry }\end{array}$ & $3.3 \%$ & $7.3 \%$ & $14.7 \%$ & $40.7 \%$ & $34.0 \%$ \\
\hline $\begin{array}{l}\text { The municipality is creating conditions for } \\
\text { businesses in the tourism sector to grow in } \\
\text { order to create more employment opportunities }\end{array}$ & $6.7 \%$ & $6.7 \%$ & $8.7 \%$ & $42.7 \%$ & $35.3 \%$ \\
\hline $\begin{array}{l}\text { Tourism has created enough employment for } \\
\text { community members in the municipal area. }\end{array}$ & $6.7 \%$ & $8.0 \%$ & $10.7 \%$ & $40.0 \%$ & $34.7 \%$ \\
\hline $\begin{array}{l}\text { Tourism provides opportunities for business } \\
\text { value chain that creates indirect employment }\end{array}$ & $0.0 \%$ & $3.3 \%$ & $6.7 \%$ & $38.7 \%$ & $51.3 \%$ \\
\hline $\begin{array}{l}\text { The infrastructure and superstructures } \\
\text { available in the municipal area are in good state } \\
\text { to support the growth of the tourism industry }\end{array}$ & $3.3 \%$ & $4.0 \%$ & $1.3 \%$ & $53.3 \%$ & $38.0 \%$ \\
\hline $\begin{array}{l}\text { The tourism industry has contributed positively } \\
\text { to poverty reduction in the municipal area }\end{array}$ & $6.7 \%$ & $9.3 \%$ & $3.3 \%$ & $39.3 \%$ & $41.3 \%$ \\
\hline
\end{tabular}

The results also indicate that the local community considers that the municipal area does not have enough tourism resources to enable tourism to be a driver for achieving local economic development goals. The results of the study further suggest that most respondents $(73.7 \%)$ consider that tourism has not created enough employment opportunities for community members in the municipal area. The views of the respondents are that the tourism industry is not creating employment opportunities for the local community members in the municipal area. The results further indicate that the 
majority (74.7\%) community members feel that the municipality does not have sufficient training programs to train the unskilled and semi-skilled to enable them to work in the tourism industry. It can therefore be inferred that if Mnquma local municipality is to use the tourism industry as a strategy for local economic development, they should invest in training of the unskilled and semi-skilled members of the community who show desire to be in the industry. Finally, the results of the study reveal that just more than half of the respondents (61.4\%) did not agree that community members are taking advantage of opportunities in the tourism industry by starting their own businesses because they understand the potential the industry has to reduce poverty.

Table 3 provides respondents views on the availability of support structures and services for the tourism industry to function optimally to contribute to local economic development. It is evident that respondents feel that there is not enough support services and infrastructure in the municipal area to support tourism industry.

Table 3. Availability of support services for the tourism industry

\begin{tabular}{|l|c|c|c|c|c|}
\hline \multicolumn{1}{|c|}{ Statements } & $\begin{array}{c}\text { Strongly } \\
\text { Agree }\end{array}$ & Agree & Neutral & Disagree & $\begin{array}{l}\text { Strongly } \\
\text { Disagree }\end{array}$ \\
\hline $\begin{array}{l}\text { There are small shopping centre facilities } \\
\text { available in my area to allow tourists to spend }\end{array}$ & $4.0 \%$ & $11.3 \%$ & $19.3 \%$ & $43.3 \%$ & $22.0 \%$ \\
\hline $\begin{array}{l}\text { Health centres in my area are in good state to } \\
\text { cater for tourist needs }\end{array}$ & $8.0 \%$ & $14.0 \%$ & $24.0 \%$ & $32.0 \%$ & $22.0 \%$ \\
\hline $\begin{array}{l}\text { There are enough attractions available for the use } \\
\text { and enjoyment of tourists }\end{array}$ & $6.7 \%$ & $18.7 \%$ & $14.7 \%$ & $33.3 \%$ & $26.7 \%$ \\
\hline $\begin{array}{l}\text { Roads in my area are in good state to support the } \\
\text { growth of tourism economic activities }\end{array}$ & $10.7 \%$ & $23.3 \%$ & $14.0 \%$ & $24.7 \%$ & $27.3 \%$ \\
\hline $\begin{array}{l}\text { The quality of electricity supply in my area is in } \\
\text { good state to support tourism economic activities }\end{array}$ & $7.3 \%$ & $14.7 \%$ & $21.3 \%$ & $26.0 \%$ & $30.7 \%$ \\
\hline
\end{tabular}

For all the statements, more than half the respondents disagreed with the statements which effectively show that they feel that the tourism industry is not supported enough to prosper to contribute to local economic development. The highest amongst these statements is where respondents do not agree that there are small shopping centre facilities available in their area to allow tourists to spend.

This result reveals limits in the ability of small businesses to make money and provide for employment opportunities in the area as alluded by Mabaso (2010) who indicated that tourism industry can bring in foreign income to a destination and therefore supports local businesses. Overall, most respondents (52\%) also felt that the roads in their area are not in a good state to support the growth of tourism economic activities, whilst $56.7 \%$ felt that the quality of electricity supply in their area is in good state to support tourism economic activities. Table 4 shows results of whether respondents feel that the municipality has prioritised tourism as a key driver for economic growth to allow for employment creation in the municipal area.

Table 4. Tourism for economic growth to create employment opportunities

\begin{tabular}{|l|c|c|c|c|c|}
\hline \multirow{2}{*}{$\begin{array}{l}\text { Municipality prioritise } \\
\text { tourism as key } \\
\text { economic driver }\end{array}$} & $\begin{array}{c}\text { Tourism } \\
\text { qualification }\end{array}$ & Disagree & Neutral & Agree & Total \\
\cline { 2 - 6 } & Yes & 56 & 7 & 5 & 68 \\
\cline { 2 - 6 } & No & 49 & 13 & 20 & 82 \\
\hline Total & & 105 & 20 & 25 & 150 \\
\hline
\end{tabular}


The results are presented based on whether the respondent has a qualification in the tourism field or not and show that most respondents (56) who have a tourism qualification believe the municipality is not prioritising tourism as a key economic driver for economic growth to allow for employment opportunities.

A similar scenario prevails where 49 respondents who do not have a tourism qualification also feels that the municipality is not prioritising tourism as a key economic driver for economic growth to allow for employment opportunities.

Table 5. Chi-Square tests for the prioritisation of tourism for economic growth

\begin{tabular}{|l|c|c|c|}
\hline & Value & df & Asymptotic significance (2-sided) \\
\hline Pearson Chi-Square & & 2 & 0.007 \\
\hline Likelihood Ratio & & 2 & 0.005 \\
\hline Linear-by-Linear Association & & 2 & 0.002 \\
\hline N of Valid Cases & 150 & & \\
\hline
\end{tabular}

A Chi-square test of independence was conducted between those with tourism qualification and those who do not have the qualification and how they viewed the prioritisation of tourism as a key driver for economic growth to create employment opportunities in the municipal area. The results revealed that there was a statistically significant association between those with tourism qualification and those who do not have the qualification in their views of the prioritisation of tourism as a key driver for economic growth to create employment opportunities in the municipal area.

The results confirm a Pearson Chi-Square of $\mathrm{X}^{2}(2)=9.925, \mathrm{p}<.0007$. The association was moderately strong with Cramer's $\mathrm{V}=0.257$. The results of the study, as shown in Table 6, indicate that the majority (59) who have a tourism qualification and (53) who do not have a tourism qualification does not agree that the tourism industry is creating employment opportunities in the municipal area. Only a few respondents (6) with a tourism qualification and (16) without a tourism qualification agreed that the tourism industry is creating employment opportunities in the municipal area.

Table 6. Results on employment creation by the tourism industry the municipal area

\begin{tabular}{|l|c|c|c|c|c|}
\hline \multirow{2}{*}{$\begin{array}{l}\text { Employment } \\
\text { creation by } \\
\text { tourism industry }\end{array}$} & Tourism qualification & Disagree & Neutral & Agree & Total \\
\cline { 2 - 6 } & Yes & 59 & 3 & 6 & 68 \\
\hline Total & No & 53 & 13 & 16 & 82 \\
\hline
\end{tabular}

This observation is in contradiction with Khalil, Kakar and Malik (2007) who noted that tourism has proven on a global scale to be an economic sector that creates opportunities of employment in both formal and informal sectors.

Table 7. Chi-Square tests for creation of employment by tourism industry

\begin{tabular}{|l|c|c|c|}
\hline & Value & $\mathrm{df}$ & Asymptotic significance (2-sided) \\
\hline Pearson Chi-Square & $9.896^{\mathrm{a}}$ & 2 & 0.007 \\
\hline Likelihood Ratio & 10.468 & 2 & 0.005 \\
\hline Linear-by-Linear Association & 7.457 & 2 & 0.006 \\
\hline N of Valid Cases & 150 & & \\
\hline
\end{tabular}

These results, therefore, imply that whilst tourism is recognised globally for its impact on employment creation, especially in developing countries, such is not the case at 
the Mnquma Local Municipality. It therefore suggests that the municipality still has a lot of work to do to advance the tourism industry to be the key driver of economic growth for employment creation. A Chi-square test of independence was conducted between those with tourism qualification and those who do not have the qualification regarding their views on creation of employment by the tourism industry in the municipal area.

The results of the study infer that there was a statistically significant association between those with tourism qualification and those who do not have the qualification regarding their views on creation of employment by the tourism industry in the municipal area, with a Pearson Chi-Square of $\mathrm{X}^{2}(2)=9.896, \mathrm{p}<.0007$.

The association is moderately strong with Cramer's $\mathrm{V}=0.257$. The research results as shown on Table 8 indicate that of the sample of community members in the study area, the majority (57) who have a tourism qualification and (80) who do not have a tourism qualification does not agree that infrastructure and superstructures available in the municipal area are in good state to support the growth of the tourism industry.

Table 8. Availability of infrastructure and superstructure to support the tourism industry

\begin{tabular}{|c|c|c|c|c|c|}
\hline & \multicolumn{3}{|c|}{$\begin{array}{l}\text { The infrastructure and superstructures available } \\
\text { in the municipal area are in good state to support } \\
\text { the growth of the tourism industry }\end{array}$} & \multirow[t]{2}{*}{ Total } \\
\hline & & Disagree & Neutral & Agree & \\
\hline \multirow{2}{*}{$\begin{array}{c}\text { Do you have } \\
\text { a tourism } \\
\text { qualification? }\end{array}$} & Yes & 57 & 2 & 9 & 68 \\
\hline & No & 80 & $\mathrm{O}$ & 2 & 82 \\
\hline \multicolumn{2}{|l|}{ Total } & 137 & 2 & 11 & 150 \\
\hline
\end{tabular}

Only a few respondents (9) with a tourism qualification and (2) without a tourism qualification agreed that infrastructure and superstructures available in the municipal area currently are in good state and adequate to support the growth of the tourism industry the tourism industry. This reinforces the challenges that confront South African local governments in leveraging tourism as a vehicle for LED (Rogerson, 2013).

Table 9. Chi-Square tests for availability of infrastructure and superstructure to support the tourism industry

\begin{tabular}{|l|c|c|c|}
\hline \multicolumn{4}{|c|}{ Chi-Square Tests } \\
\hline & Value & $\mathrm{df}$ & Asymptotic Significance (2-sided) \\
\hline Pearson Chi-Square & $9.088^{\mathrm{a}}$ & 2 & 0.011 \\
\hline Likelihood Ratio & 10.162 & 2 & 0.006 \\
\hline Linear-by-Linear Association & 7.908 & 1 & 0.005 \\
\hline N of Valid Cases & 150 & & \\
\hline
\end{tabular}

Finally, a chi-square test of independence was conducted between those with tourism qualification and those who do not have the qualification regarding their views on availability of infrastructure and superstructures to support the tourism industry. The results disclose there was a statistically significant association between those with tourism qualification and those who do not have the qualification regarding their views on availability of infrastructure and superstructures to support the tourism industry with the Pearson Chi-Squared at $\mathrm{X}^{2}(2)=9.088, \mathrm{p}<.011$.

The association was moderately small with Cramer's V $=0.246$. 


\section{CONCLUSIONS}

Tourism has proven on a global scale to be an economic sector that creates opportunities of employment in both formal and informal sectors (UNWTO, 2000). In sub-Saharan Africa, there is much interest by national governments in the promotion of tourism for achieving national development objectives (Rogerson \& Rogerson, 2018). The critical importance of tourism, also, for local economic development is gaining widespread attention. Tourism has been viewed as a key potential driver for local economic development objectives, which are sustainable employment, poverty alleviation and economic growth. South Africa must be regarded as one of the leaders in the application of tourism as a vehicle in local economic development planning in the continent of Africa (Nel \& Rogerson, 2005; Rogerson, 2014).

This paper addresses modestly a knowledge gap in the existing debates around tourism and LED initiatives in South Africa, where tourism is a priority sector in local development planning across the country (Nel \& Rogerson, 2016). The focus was upon the perceptions of local community towards the role of tourism as a driver for local development. The study was conducted in a remote area of Eastern Cape province, South Africa. The results clearly indicate that the local municipality faces many challenges for tourism to achieve the objectives for LED in the area and, most especially, to address the problems of unemployment and poverty. The findings reveal that community members consider that using tourism as a strategy for economic development does not necessarily results in positive results in terms of employment creation and improvement of their standard of living. The results suggest that in the South African context, where much policy focus is upon tourism and LED, more research is required on community views of the usage of tourism as a strategy for attaining the objectives for local economic development especially in the country's distressed areas with the highest levels of recorded poverty and unemployment.

\section{REFERENCES}

Ashley, C., De Brine, P., Lehr, A., \& Wilde, H. (2007). The Role of the Tourism Sector in Expanding Economic Opportunity. Economic Opportunity Series. Cambridge, Mass: Harvard University.

Barberia, L.G. \& Biderman, C. (2010). Local economic development: Theory, evidence, and implications for policy in Brazil. Geoforum, 41, 951-962.

Drummond, F. \& Snowball, J. (2019). Cultural clusters as a local economic development strategy in rural, small town areas: The Sarah Baartman District in South Africa. Bulletin of Geography: Socio-Economic Series, 43, 107-119.

Fox, W. \& Bayat, M.S. (2007). A Guide to Managing Research. Cape Town: Juta.

Khalil, S., Kakar, M.K., \& Malik, A. (2007). Role of tourism in economic growth: Empirical evidence from Pakistan economy. The Pakistan Development Review, 46 (4), 985-995.

Kimbu, A.N., \& Tichaawa, T.M. (2018). Sustainable development goals and socio-economic development through tourism in Central Africa: Myth or reality? GeoJournal of Tourism and Geosites, 23 (3), 780-796.

Kruja, D., Lufi, M., \& Kruja, I. (2012). The role of tourism in developing countries: The case of Albania. European Scientific Journal, 8 (19), 129-141.

Lawrence, F. \& Rogerson, C.M. (2018). Local economic development agencies and place-based development: Evidence from South Africa. Bulletin of Geography: Socio-Economic Series, 41, 29-43.

Lawrence, F. \& Rogerson, C.M. (2019). Local economic development agencies and peripheral small-town development: Evidence from Somerset East, South Africa. Urbani izziv, 30 (Supplement) 144-157.

Mabaso, S.L. (2010). The impact of tourism on the local community of Bergville. M-Tech dissertation, Tourism and Hospitality, Durban University of Technology.

Nel, E. \& Rogerson, C.M. (2005). Local Economic Development in the Developing World: The Experience of Southern Africa. New Brunswick (NJ) and London: Transaction Press.

Nel, E. \& Rogerson, C.M. (2016). The contested trajectory of applied local economic development in South Africa. Local Economy, 31(1-2), 109-123. 
Pike, A., Rodriguez-Pose, A., \& Tomaney, J. (2011). A Handbook of Local and Regional Development. London: Routledge.

Ramukumba, T. (2012). The Local Economic Development in the Eden District Municipality, Western Cape Province, South Africa: A case study of emerging entrepreneurs in the tourism industry. American Journal of Tourism Research, 1(1), 9-15.

Rodriguez-Pose, A. \& Tijmstra, S.A.R. (2007). Local economic development in sub-Saharan Africa. Environment and Planning C: Government and Policy, 25, 516-536.

Rogerson, C.M. (2013). Tourism and local development in South Africa: Challenging local governments. African Journal for Physical, Health Education, Recreation and Dance, 19 (Supplement 2), 9-23.

Rogerson, C.M. (2014). Reframing place-based economic development in South Africa: The example of local economic development. Bulletin of Geography: Socio-Economic Series, 24, 203-218.

Rogerson, C.M. (2017). Less visited tourism spaces in South Africa. African Journal of Hospitality, Tourism and Leisure, 6 (3), 1-17.

Rogerson, C.M. (2019). Revamping local economic development policy in South Africa. In J. Knight \& C.M. Rogerson (eds.) Geography of South Africa: Contemporary Changes and New Directions. Cham: Springer International, 253-259.

Rogerson, C.M. \& Nel, E. (2016). Planning for local economic development in spaces of despair: Key trends in South Africa's distressed areas. Local Economy, 31 (1-2), 124-141.

Rogerson, C.M. \& Rogerson, J.M. (2010). Local economic development in Africa: Global context and research directions. Development Southern Africa, 27, 465-480.

Rogerson, C.M. \& Rogerson, J.M. (2012). Business development and local economic development in South Africa: addressing the disconnect. Acta Academica, 44 (2), 41-69.

Rogerson, C.M. \& Rogerson, J.M. (2014). Agritourism and local economic development in South Africa. Bulletin of Geography: Socio-Economic Series, 26, 93-106.

Rogerson, C.M. \& Rogerson, J.M. (2018). Africa's tourism economy: Uneven progress and challenges. In: T. Binns, K. Lynch \& E. Nel (eds.), The Routledge Handbook of African Development. Abingdon: Routledge, 545-560.

Rogerson, C.M. \& Rogerson, J.M. (2019a). Tourism, local economic development and inclusion: Evidence from Overstrand Local Municipality, South Africa. GeoJournal of Tourism and Geosites, 25 (2), 293-308.

Rogerson, C.M. \& Rogerson, J.M. (2019b). Tourism and accommodation services in South Africa: A spatial perspective. In J. Knight \& C.M. Rogerson (eds.) Geography of South Africa: Contemporary Changes and New Directions. Cham: Springer International, 213-220.

Rogerson, C.M. \& Saarinen, J. (2018). Tourism for poverty alleviation: issues and debates in the global South. In C. Cooper, S. Volo, B. Gartner \& N. Scott (eds), The SAGE Handbook of Tourism Management: Applications of Theories and Concepts to Tourism. London: Sage, 22-37.

Sarantakos, S. A. (2007). Toolkit for quantitative data analysis, Palgrave. MacMillan, Hampshire.

Tashakkori, A. \& Teddlie, C. (2003). Handbook on mixed methods in the behavioural and social science. Thousand Oaks: Sage.

Van der Merwe, C.D. \& Rogerson, C.M. (2018). The local development challenges of industrial heritage in the developing world: evidence from Cullinan, South Africa. GeoJournal of Tourism and Geosites, 21 (1), 186-199.

Welman, J. C. \& Kruger, S. J. (2001). Research Methodology - for the Business and Administrative Sciences. 2nd ed. Cape Town: Oxford University Press.

*** United Nations World Tourism Organization (UNWTO). (2000). Sustainable Development of Tourism: A Compilation of Good Practices. Madrid: UNWTO.

Submitted:

26.04.2019
Revised:

08.07.2019
Accepted and published online 30.07.2019 